\title{
Estado e economia no institucionalismo de Douglass North
}

State and economics in institutionalism of Douglass North

RONALDO FIANI*,**

RESUMO: As ideias de Douglass North, apesar de seu prêmio Nobel de 1993, ainda são pouco conhecidas entre os economistas brasileiros. Esse desconhecimento é deplorável não apenas pela relevância de suas ideias para a teoria atual do desenvolvimento, mas também por sua nova (e bastante heterodoxa) contribuição para a análise do papel econômico do Estado moderno. Este artigo apresenta uma síntese da discussão de North sobre o papel institucional do Estado no sistema econômico. Mostra-se que, no pensamento de North, esse papel compreende não apenas a aplicação dos direitos de propriedade, mas, mais importante, a definição e atribuição desses direitos.

PALAVRAS-CHAVE: Douglass North; Estado; institucionalismo.

ABSTRACT: Douglass North's ideas, notwithstanding his 1993's Nobel award are still barely known among Brazilian economists. This unawareness is deplorable not only because the relevance of his ideas to current development theory but also for his new (and rather heterodox) contribution to the analysis of the modern State's economic role. This paper presents a synthesis of North's discussion concerning the institutional role of the State in the economic system. It is shown that in North's thought that role comprehends not only the enforcement of property rights but more importantly the definition and attribution of those rights.

KEYWORDS: Douglass North; State; institutionalism.

JEL Classification: B15; O43; P48.

\section{INTRODUÇÃO}

Apesar de Douglass North ter sido premiado com o Nobel de Economia em 1993, "for having renewed research in economic history by applying economic theory and quantitative methods in order to explain economic and institutional

\footnotetext{
* Professor do Instituto de Economia da Universidade Federal do Rio de Janeiro - UFRJ, Rio de Janeiro/RJ, Brasil. E-mail:

** O autor agradece as sugestões de dois pareceristas anônimos da REP.
} 
change", conforme a justificativa então apresentada, seu pensamento ainda é pouco conhecido no Brasil.

$\mathrm{Na}$ verdade, a pouca divulgação de suas idéias no Brasil em grande medida se explica pelo fato de que o desenvolvimento da análise de North teve lugar durante um período bastante longo: do início dos anos 70 até a primeira metade dos anos 90. Vários conceitos sofreram elaboração durante esse período, alguns que tinham destaque na sua agenda de pesquisa, no início de sua investigação, foram sendo progressivamente redefinidos e até mesmo posteriormente abandonados, de acordo com a evolução de sua análise.

Dessa forma, tanto as dificuldades envolvidas no estudo das idéias de North, como o reconhecimento internacional que obtiveram, justificam o esforço de tentar sintetizar seu pensamento. Essa síntese, contudo, não pode ser apenas uma resenha indiferente de suas idéias e conceitos. Dado o próprio caráter dinâmico de seu pensamento, com conceitos tendo sido revistos e até mesmo descartados a partir de um exame crítico de sua consistência lógica ou de sua confirmação histórica, pelo próprio North, uma síntese do seu pensamento tem de ser igualmente crítica, apontando os aspectos ainda não suficientemente elaborados ou as inconsistências remanescentes.

Dentro dessa perspectiva crítica, é preciso identificar uma questão central no pensamento de North, tanto para focar a discussão e desconsiderar aspectos secundários, como para reconhecer os aspectos originais de sua contribuição. Será então argumentado que o aspecto mais original da contribuição de North, e aquele em que concentra todo o esforço para o aprimoramento de sua análise, é a questão do papel institucional do Estado. O objetivo aqui não será, portanto, apresentar uma resenha com todos os desdobramentos da evolução do pensamento de North, mas destacar os principais pontos de sua análise para uma discussão do papel institucional do Estado.

Antes de considerar especificamente o papel institucional do Estado para Douglass North, é necessário apresentar seu modelo de análise histórica, uma vez que North deduz a relação entre Estado e instituições a partir de um modelo mais geral, que permite analisar "the changing structure of economics over time" (North, 1984, p. 203). Isto é, trata-se de formular um modelo que permita tratar do processo de desenvolvimento econômico, por meio da análise de suas instituições.

\section{INSTITUIÇÕES E DESENVOLVIMENTO ECONÔMICO NO PENSAMENTO DE DOUGLASS NORTH}

Uma característica fundamental da análise de North é a rejeição da teoria neoclássica como modelo de interpretação no estudo da história econômica. North observa que:

"There is a persistent tension in the social sciences between the theories we construct and the evidence we compile about human interaction in 
the world around us. It is most striking in economics, where the contrast between the logical implications of neoclassical theory and the performance of economies (however defined and measured) is startling" (North, 1990, p. 11).

O interesse fundamental para North, ao estudar a história econômica, é explicar as suas instituições como determinantes do desempenho econômico das sociedades. Para isto a teoria neoclássica é insatisfatória: ela não só não fornece insights para a compreensão mais adequada do manor feudal, das feiras de Champange ou do suq no Oriente Médio e Norte da África, como não explica a permanência de formas de troca ineficientes por séculos (North, 1990, p. 11).

Com efeito, o problema da permanência de instituições que desfavorecem o crescimento econômico é uma das preocupações centrais de Douglass North. E, com relação a esse problema, a questão dos direitos de propriedade, isto é, de sua definição e garantia, assume papel fundamental. Esse foi um dos aspectos de mais significativa mudança no pensamento de North. Com efeito, em North e Thomas (1973), a definição dos direitos de propriedade varia em resposta às mudanças nos preços relativos da terra e do trabalho, mudanças essas causadas pelos ciclos de crescimento e redução da população européia durante a Idade Média.

Assim é que cada ciclo de expansão da população barateava os salários e aumentava o valor da terra, não apenas pela maior escassez relativa desta última, mas também pela maior demanda por alimentos o que aumentava o rendimento esperado do cultivo. A conseqüência era um maior recurso, por parte dos senhores feudais, a novas formas de arrendamentos, e menor apelo às obrigações de prestação de serviços em suas terras. Quando fatores, tais como a peste, reduziam a população, a conseqüência era o aumento dos salários pela maior escassez relativa do trabalho e o barateamento da terra, com o conseqüente recrudescimento das obrigações feudais nas terras do senhor. Dessa forma, os direitos de propriedade mudavam em função de um processo (ainda que não totalmente deliberado) de análise custo-benefício.

Posteriormente, contudo, North vai reconsiderar esse modelo. A mudança no tratamento dos direitos de propriedade foi provocada pela constatação, em vários casos históricos, da permanência de direitos de propriedade ineficientes do ponto de vista econômico, por longos períodos. Isso ia de encontro à noção do processo de definição desses direitos como resultante do cálculo de custo e benefício, derivado dos preços relativos dos fatores. Com efeito, em sua obra de 1981, Structure and Change in Economic History, North afirma que:

"The reason for the differential growth rates among the merging nationstates of Europe during the seventeenth century is to be found in the nature of property rights that had developed in each. The type of property rights established was the outgrowth of the particular way each nationstate developed" (North, 1981, p. 148). 
Assim, o desenvolvimento dos direitos de propriedade deixa de ser dado por um processo geral de determinação, via mudanças dos preços relativos dos fatores, e passa a ser resultado das especificidades do desenvolvimento de cada nação. Antes de se apresentar, contudo, o que determina a especificidade desse desenvolvimento, é necessário estudar mais em detalhe o modelo de análise histórica de North, assim como o papel que os direitos de propriedade possuem nesse modelo.

Inicialmente, é preciso considerar o conceito de instituição com que North trabalha: "Institutions are the rules of the game in a society; more formally, they are the humanly devised constraints that shape human interaction. In consequence they structure incentives in exchange, whether political, social or economic" (North, 1992,

p. 5). Assim, North vê as instituições essencialmente como sistemas de incentivos em qualquer tipo de troca e é justamente como sistemas de incentivos que as instituições se relacionam com os direitos de propriedade.

Dada a existência dos custos de transação, que, ao contrário do que supõe a teoria neoclássica, são significativos (North, 1992, p. 5-6), serão esses custos que definirão os ganhos derivados da troca. North caracteriza assim os custos de transação: "It is the cost of measuring the valuable attributes of the goods and services or the performance of agents in exchange that is the fundamental key to the cost of transacting" (North, 1992, p. 7). Na medida em que as mercadorias possuem múltiplos atributos e os serviços múltiplas características, existem custos em identificar e mensurar todos esses atributos, no momento de especificar os termos do contrato ou de verificar e garantir sua execução. $\mathrm{Na}$ medida em que esses custos são elevados ou incertos, os direitos de propriedade acabam por ser especificados de forma imperfeita ou incompleta.

Os ganhos derivados da troca estão diretamente relacionados, portanto, à definição e garantia dos múltiplos atributos que compõem os direitos de propriedade. Quanto mais bem definidos e mais garantidos forem esses direitos, mais eficientes serão as instituições como sistema de incentivos ao desenvolvimento econômico das nações. Em grande medida os custos de verificação e garantia dos direitos de propriedade podem ser reduzidos, em primeiro lugar, na medida em que os vínculos entre os agentes possuam natureza mais pessoal:

"By personal exchange, I refer to a world in which we deal with each other over and over again in small-scale economic, political and social activity, where everybody knows everybody, and where under those conditions, to use a simple illustration from game theory, it pays to co-operate. That is, game theory says that human beings co-operate with each other when they play a game over and over again, when there is no end game, when they know the other parties to exchange, and when there are small numbers" (North, 1999, p. 21).

Mas esse não é o mundo da sociedade moderna, pelo menos o mundo que surgiu com a indústria química alemã, na segunda metade do século XIX: 
"The world that it has produced is characterized by impersonal exchange. It is a world in which our dependence rests upon people all over the world, whom we do not know; there are no repeated dealings; and large numbers of players are involved. Therefore it is a world in which the game is played differently. In game theory, we say such a world is one in which it pays to defect" (North, 1992, p. 21).

Essa distinção entre relações econômicas baseadas em trocas pessoais e relações econômicas baseadas em trocas impessoais é de fundamental importância, não apenas para a compreensão do papel que as instituições desempenham na análise de Douglass North, mas principalmente para a compreensão do papel que atribui ao Estado, no campo das instituições econômicas. Anteriormente North já tinha sido bastante explícito em relação à relevância dessa distinção, assim como no que diz respeito às suas conseqüências:

"The measured transaction costs of a society where there is a dense social network of interaction is very low. [...] Under such conditions, norms of behavior are seldom written down. Formal contracting does not exist, and there are few formal specific rules. However, while measured transaction costs are low [...] production costs are high, because specialization and division of labor are limited to the extent of markets that can be defined by personal exchange" (North, 1989, p. 1320).

Dessa forma, o universo econômico representado como uma ordem espontânea, onde normas e convenções culturalmente sedimentadas, das quais os indivíduos possuem pouca consciência, governam as relações econômicas, pode ser considerado como uma situação de baixos custos de transação, mas elevados custos de produção. Mas esse não é um modelo adequado para representar as sociedades ocidentais modernas:

"At the other extreme from personal exchange is a world of specialized interdependence in which the well-being of individuals depends upon a complex structure characterized by individual specialization and hence by exchange ties that extend both in time and space. A pure model of this world of impersonal exchange is one in which goods and services or the performance of agents is characterized by many valued attributes, in which exchange takes place over time, and in which there are not repeated dealings. Under these forms of exchange, the costs of transacting can be high, because there are problems both in measuring the attributes of what is being exchanged and problems of enforcing the terms of exchange; in consequence there are gains to be realized by engaging in cheating, shirking, opportunism etc. [...] As a result, in modern Western societies we have devised formal contracts, bonding of participants, guarantees, brand names, elaborate monitoring systems, and effective 
enforcement mechanisms. In short, we have well-specified and well-enforced property rights" (North, 1989, p. 1320).

A passagem citada acima, embora extensa, é muito importante, na medida em que estabelece com muita precisão os limites da ordem espontânea e seu interesse menor para o estudo das instituições econômicas, nas modernas sociedades ocidentais. A divisão crescente do trabalho nas economias modernas exige o desenvolvimento de uma estrutura institucional que dê conta do aumento progressivo da complexidade nas interações entre os agentes econômicos. Os requisitos dessa estrutura institucional e o papel do Estado são assim definidos por North:

"The institutional requirements that are necessary in order to be able to realize the productivity gains associated with the model of impersonal exchange outlined above entail both the development of efficient products and factor markets and of a medium of exchange with reliable features. The establishment of such a set of property rights will then allow individuals in highly complex interdependent situations to be able to have confidence in their dealings with individuals of whom they have no personal knowledge and with whom they have no reciprocal and ongoing exchange relationships. This is only possible as the result, first, of the development of a third party to exchanges, namely government, which specifies property rights and enforces contracts; and second of the existence of norms of behavior to constraint the parties in interaction...” (North, 1989, p. 1320, grifos nossos).

Dessa forma, ainda que normas e convenções também desempenhem um papel ao viabilizar as interações econômicas dos agentes, papel destacado é atribuído ao Estado por North, como fundamento das instituições em sociedades baseadas em trocas impessoais e complexas. Essa constatação do papel de destaque do Estado nas sociedades modernas fornece o ponto de partida para responder à pergunta acerca dos motivos da permanência de direitos de propriedade ineficientes:

"The answer is quite clear: The breakdown of personal exchange is not just the breakdown of a dense communication network, but it is the breakdown of communities of common ideologies and a common set of rules in which all believe. The rise of impersonal rules and contracts means the rise of the state, and with it unequal distribution of coercive power. This provides the opportunity for individuals with superior coercive power to enforce the rules to their advantage, regardless of their effects on efficiency" (North, 1989, p. 1321).

Do trecho transcrito acima duas conclusões podem ser extraídas: em primeiro lugar, que o compartilhamento de experiências e valores, que torna viável o estabelecimento de um ponto focal coordenando as ações dos agentes, se torna muito mais limitado em uma sociedade moderna e complexa, baseada em trocas impes- 
soais. Em segundo lugar, que o surgimento do Estado transforma o estabelecimento de regras em resultado do processo de barganha política, sem relação necessária com a eficiência econômica.

Outro fator muito importante para que os custos de verificar e de garantir os direitos de propriedade sejam baixos é que a ideologia dos agentes seja relativamente homogênea, de tal forma que eles interpretem a realidade em que vivem da mesma forma (North, 1992, p. 8; 1984, p. 207). Contudo, não se deve esperar também por homogeneidade ideológica nas sociedades modernas:

"To the degree that the members of a society have the same ideological framework, the formal rules of the society that define the constraints making up institutions will not have to be defined very clearly and enforcement mechanisms and procedures may be minimal or even absent together. But to the degree that society has diverse ideologies reflecting the growth of specialization and division of labor, more resources will have to be devoted, first to defining the rules precisely, and second to enforcing those rules" (North, 1984, p. 207).

Em seguida, North detalha mais esse ponto:

"With simple political and economic organization, custom may be sufficient to specify the structure with a consensus ideology. As the gains from trade that arise from specialization and division of labor result in more and more complex forms of political and economic organization, the resource costs of capturing those gains from trade will increase. They will increase not only because the costs of measurement and enforcement of an ever-lengthening chain that result from greater and greater specialization will grow, but also because ideological alienation will characterize the relations between participants in the exchange process and will require greater and greater amounts of resources devoted to specification and enforcement of contracts" (North, 1984, p. 207).

North considera, assim, característica da modernidade a diferenciação crescente das visões de mundo dos agentes, que formam suas ideologias, ${ }^{1}$ relegando o

\footnotetext{
${ }^{1}$ North define ideologia como a percepção subjetiva que um indivíduo possui da realidade e que ele utiliza tanto para explicar como o mundo ao seu redor funciona, incluindo-se aqui a sua história até o presente, como para determinar como ele deveria funcionar. Dessa forma, a ideologia em North é tanto um modelo subjetivo de análise da realidade, quanto um modelo normativo de intervenção nessa mesma realidade. Será com base nesses modelos que os indivíduos e os grupos sociais vão estabelecer padrões de interação social. Essa percepção subjetiva é necessariamente incompleta, na medida em que os indivíduos possuem racionalidade limitada, mas pode ter dimensão tanto individual, na forma das crenças pessoais que determinam o comportamento individual, como coletiva, tais como as religiões e o comunismo (North, 1990, p. 23).
} 
papel do costume e da tradição como elementos de coesão social (e de redução dos custos de transação) apenas às sociedades primitivas.

Assim, a definição e garantia dos direitos de propriedade possui papel fundamental no estudo da história econômica. Com efeito, North cita vários exemplos históricos de direitos de propriedade mal definidos, ou ainda definidos de forma ineficiente, por longos períodos de tempo. Um exemplo apontado é o direito das guildas de pastores de ovelhas na Espanha, as Mestas, de levarem suas ovelhas através do país, inclusive de impedir o fechamento das terras cultivadas a sua passagem. A garantia desse direito medieval foi consolidada por meio da criação, em 1273, da Honorável Assembléia da Mesta dos Pastores de Castela. No século XVI o conselho da Mesta era uma instituição privilegiada e o direito à livre movimentação dos rebanhos teria atrasado, de acordo com North, o desenvolvimento de direitos eficientes de propriedade na agricultura espanhola por séculos (North, 1981, p. 150-151).

A tendência verificada por North com o desenvolvimento da divisão de trabalho, de progressiva formalização das instituições responsáveis pela definição e garantia dos direitos de propriedade, põe em destaque a ação institucional do Estado na definição e garantia desses direitos. Esse será o próximo tema discutido por North a ser abordado.

\section{A AÇÃO INSTITUCIONAL DO ESTADO NA ECONOMIA SEGUNDO DOUGLAS NORTH}

O exemplo histórico da Mesta espanhola exemplifica a importância do papel do Estado na definição dos direitos de propriedade. Isso é decorrência da visão de North, apresentada anteriormente, da sociedade de trocas impessoais, com elevado grau de especialização e divisão do trabalho, demandando uma maior intervenção deliberada na formulação das instituições. O próximo ponto a ser abordado será então a ação institucional do Estado segundo North.

A relevância do Estado se coloca, inicialmente, quando consideramos o processo de mudança institucional. De acordo com North, devemos considerar que a iniciativa das reformas institucionais deve partir com mais frequiência dos governos: "... institutional innovation will come from rulers rather than constituents since the latter would always face the free rider problem" (North, 1981, p. 28).

O Estado é também diretamente responsável pelo desempenho da economia, não apenas nos momentos de reforma institucional, mas também pela especificação corrente dos direitos de propriedade:

"A theory of the state is essential because it is the state that specifies the property rights structure. Ultimately it is the state that is responsible for the efficiency of the property rights structure, which causes growth or stagnation or economic decline" (North, 1981, p. 17). 
Eis como North caracteriza o Estado:

"A state is an organization with a comparative advantage in violence, extending over a geographic area whose boundaries are determined by its power to tax constituents. The essence of property rights is the right to exclude, and an organization which has a comparative advantage in violence is in the position to specify and enforce property rights" (North, 1981, p. 21).

O Estado, caracterizado assim, não seria, contudo, apenas uma "arena política" onde se enfrentam os interesses sociais. É um agente com objetivos próprios, ao menos dentro de certos limites:

"In fact, the property rights which emerge are a result of an on-going tension between the desires of the rulers of the state, on the one hand, and the efforts of the parties to exchange to reduce transaction costs, on the other. This simple dichotomy actually is anything but simple, since the parties to an exchange will devote resources to influencing the political decision makers to alter the rules. But at least as an initial starting point for theorizing, it is useful to separate a theory of the state from a transaction cost approach to property rights" (North, 1981, p. 18).

Para desempenhar essa função (vender proteção e justiça), o governo age monopolizando a definição e a garantia dos direitos de propriedade (North e Thomas, 1973, p. 97). Como remuneração por esse serviço, o governo arrecada imposto. Essa transação (o pagamento de impostos por parte da sociedade em troca de proteção e justiça, isto é, da definição e garantia dos direitos de propriedade) é vantajosa, na medida em que o Estado possui economias de escala nessas tarefas e, portanto, seria mais custoso para os agentes privados desempenhar essas tarefas por si próprios. Na medida em que essas economias de escala não sejam exauridas, a ampliação das funções de proteção e garantia dos direitos de propriedade aumenta a renda de toda a comunidade, gerando uma poupança a ser dividida entre a sociedade e o Estado.

É importante destacar que essa função característica do Estado, de vender proteção e garantia de direitos de propriedade para a sociedade, de acordo com North e Thomas não mudou desde a constituição dos estados modernos, mas permanece essencialmente a mesma até os nossos dias (North e Thomas, 1973, p. 97).

Retornando à questão da poupança gerada pela garantia dos direitos de propriedade por parte do Estado, a pergunta seguinte a ser feita é como será dividida essa poupança entre a sociedade e o Estado. Obviamente há uma base de disputa sobre os ganhos incrementais resultante dessa troca: o Estado vai procurar capturar o máximo possível da renda adicional gerada, o mesmo valendo para a sociedade. Em uma formulação inicial dos determinantes dessa repartição, North e Thomas observam que: "The more monopoly power an existing prince could claim 
- that is, the less close or threatening were his rivals - the greater the percentage of rents which the state could appropriate" (North e Thomas, 1973, p. 98).

Essa formulação inicial vai ser mais elaborada em North (1981), no que ele denominou "modelo neoclássico do Estado". Partindo-se de um Estado com um governante maximizador de utilidade, North estabelece três características do seu modelo. A primeira, que define o processo de troca entre o governante e seus governados, afirma que a renda em uma sociedade, onde o Estado garante os direitos de propriedade dos governados, é maior do que caso os governados garantissem eles próprios os seus direitos, dadas as economias de escala do Estado nessas tarefas.

A segunda, que define os termos de troca entre governantes e governados, afirma que o Estado tenta agir como um monopolista discriminador, separando grupos de governados de forma a atribuir direitos de propriedade que maximizem a receita do Estado. A terceira, que também define os termos de troca entre governantes e governados, afirma que o Estado enfrenta restrições na sua atuação como monopolista discriminador na medida em que sempre existem rivais potenciais para o mesmo tipo de serviços (North, 1981, p. 23).

Passa então North a explorar essas três hipóteses do seu modelo neoclássico do Estado. Sobre a primeira hipótese, afirma que:

"The basic services that the state provides are the underlying rules of the game. Whether evolving as a body of unwritten customs (as in the feudal manor) or as a written constitution, they have two objectives: one, to specify the fundamental rules of competition and cooperation which will provide a structure of property rights (that is, specify the ownership structure in both factor and product markets) for maximizing the rents accruing to the ruler; two, within the framework of the second objective, to reduce transaction costs in order to foster maximum output of the society and, therefore, increase tax revenues accruing to the state" (North, 1981, p. 24).

Em relação a esses objetivos, North faz três observações: 1) eles não são necessariamente consistentes, pois não necessariamente o conjunto de regras institucionais que maximiza a receita do Estado é aquele que determina direitos de propriedade que maximizam o produto social (North, 1981, pp. 24-5); 2) existem problemas do tipo agente-principal entre o governante e sua burocracia (mais tarde, irá observar que, na medida em que os interesses dos agentes nem sempre coincidem com os interesses do governante, alguma dissipação das rendas de monopólio do governante sempre irá acontecer, inclusive por meio de coalisão entre os agentes e os constituintes (North, 1981, p. 27); 3) Os serviços fornecidos pelo governante possuem diferentes curvas de oferta: alguns são bens públicos, outros têm a curva de oferta com formato de U (North, 1981, p. 25).

Conclui então ele sobre a determinação da ação do Estado:

"The ruler will specify a set of property rights designed to maximize his monopoly rents for each separable part of the economy by monitoring 
and metering the inputs and outputs of each. The costs of measuring the dimensions of the inputs and outputs will dictate the various property rights structure for the diverse sectors of the economy, which therefore will be dependent on the state of the technology of measurement" (North, 1981, p. 26).

Dessa forma, North estabelece uma relação entre definição dos direitos de propriedade e tecnologia de mensuração, que se dá pelo objetivo do Estado de maximizar sua receita tributária. North admite, porém, limitações a essa forma de ação por parte do Estado:

"The ruler always has rivals: competing states or potential rulers within his own state. The latter are analogous to the potential rivals to a monopolist. Where there are no close substitutes, the existing ruler characteristically is a despot, a dictator, or an absolute monarch. The closer the substitutes, the fewer degrees of freedom the ruler possesses, and the greater the percentage of incremental income that will be retained by the constituents” (North, 1981, p. 27).

Não apenas em termos de renda a competição entre governantes se faz sentir:

"The opportunity cost of each of the various constituents will be different and will dictate the bargaining power each group has in the specification of property rights, as well as the tax burden it will incur. Opportunity costs will also dictate allocation of services provided by the ruler to the degree that they are not pure public goods, since the ruler will provide greater services to those with close alternatives than to those with none" (North, 1981, p. 27).

Assim, a determinação de uma dada estrutura de direitos de propriedade e a oferta de serviços pelo Estado estão condicionadas pelo poder de barganha relativo dos grupos na sociedade. North considera ainda que: "Constituents may, at some cost, go over to a competing ruler (that is, another existing political-economic unit) or support a competitor for ruler within the existing state" (North, 1981, p. 27).

Infelizmente, North não elabora suficientemente essas considerações para $o$ caso do Estado democrático moderno. Com efeito, após a formulação da sua teoria neoclássica do Estado, North reconheceu explicitamente os problemas representados pela democracia moderna em seu modelo:

"The model of the state is deficient in other ways too, but it is particularly deficient when we move from a single ruler to the modern pluralist state. A theory of the resolution of the conflicts in such a state has baffled modern political scientists" (North, 1981, p. 68). 
A evolução do pensamento de Douglass North com relação ao papel institucional do Estado na economia alcançou seu ponto culminante em sua obra Institutions, Institutional Change and Economic Performance (North, 1990), quando ele se afastou da noção de Estado construída em seu livro anterior, Structure and Change in Economic History (North, 1981), o seu "modelo neoclássico de Estado". Em North (1990), há uma preocupação evidente em aprofundar a inter-relação entre o político e o econômico, para além da simples relação entre o governante em busca de receita fiscal e a sociedade que demanda a definição de direitos e oferta de bens públicos. Assim é que observa North:

"The existing structure of rights (and the character of their enforcement) defines the existing wealth-maximizing opportunities of the players, which can be realized by forming either economic or political exchanges. Exchange involves bargains made within the existing set of institutions, but equally the players at times find it worthwhile to devote resources to altering the more basic structure of the polity to reassign rights" (North, 1990, p. 47).

Desta forma, transações políticas ou econômicas são tornadas equivalentes, como formas válidas de os agentes realizarem os ganhos que uma dada estrutura de direitos possibilita: mais uma vez se observa que o plano econômico e o plano político se entrelaçam. Mais importante ainda, faz parte das possibilidades estratégicas dos agentes, desde que assim considerem ser conveniente, investir em mudanças na estrutura política da sociedade, visando a uma redefinição de direitos de propriedade e, conseqüentemente, a redefinição das oportunidades de ganho. Obviamente, há uma grande diferença aqui em relação ao modelo de Estado em que o governante negocia a definição de direitos e oferta de bens públicos em troca de receita fiscal: North (1990) reconhece em seu modelo uma multiplicidade de agentes, que eventualmente podem investir na própria redefinição da estrutura política que define e garante direitos de propriedade.

Em North (1990) o modelo neoclássico do Estado é apresentado como "a simplified model" e claramente posicionado no argumento como uma primeira abordagem (North, 1990, p. 48). O modelo em seguida é revisto, inicialmente, para incluir os órgãos representativos que se constituíram nos princípios da Europa moderna, órgãos tais como parlamentos, estados gerais e cortes (North, 1990, p. 49), resultantes da necessidade do governante de negociar o aumento de sua receita fiscal, o que exigia oferecer uma contrapartida em serviços aos grupos sociais.

Em seqüência, North revê de forma ainda mais radical seu modelo inicial do Estado, ao estabelecer claramente suas limitações históricas:

"When we move from the historical character of representation in early modern Europe to modern representative democracy, our story is complicated by the development of multiple interest groups and by a much more 
complicated structure devised to facilitate (again given relative bargaining strength) the exchange between interest groups" (North, 1990, p. 49).

Assim, o modelo simples de um governante atuando como monopolista discriminador no momento de trocar seus serviços por receita fiscal fica severamente comprometido para as democracias modernas, com seus múltiplos grupos de interesse e sua complexa estrutura institucional. A complexidade da estrutura institucional nos regimes democráticos é, ela mesma, resultante da multiplicidade de grupos de interesse, o que impede que membros do Estado tenham a possibilidade de decidir autonomamente, como seria mais adequado ao modelo do governante monopolista discriminador:

"Because there are multiple interest groups, no particular interest group that a legislator may represent can form a majority. Therefore, legislators cannot succeed acting alone, but make agreements with other legislators, with different interests" (North, 1990, p. 50).

Não se trata mais agora da personificação do Estado na figura de um "governante", mas no reconhecimento de uma estrutura mais complexa, composta por legisladores que interagem entre si e com seus representantes. Isso transfere o foco de análise para uma outra questão bastante difícil: os determinantes do comportamento do legislador. A discussão desses determinantes envolve a análise da atuação de "caroneiros" (free-riders) e de valores como justiça e eqüidade, questões a respeito das quais North observa que:

"These issues appear to show in the voting behavior of legislators; it is widely observed that one cannot explain the voting behavior of legislators within the narrow confines of a principal/agent model, in which the agent (the legislator) is faithfully pursuing the interests of the principal (constituents). The agent's own utility function - his or her own sense of the way the world ought to be - appears to play a role in the outcomes" (North, 1990, p. 21).

O reconhecimento de que os legisladores possuem seus próprios objetivos, derivados de suas concepções normativas acerca do mundo em que vivem, nos leva a um novo problema: o da utilização do poder por esses agentes. Em outro contexto, discutindo o papel do Estado na garantia dos direitos de propriedade, North sintetiza o problema: "Put simply, if the state has coercive force, then those who run the state will use that force in their own interest at the expense of the rest of society" (North, 1990, p. 59). Isso não apenas no caso de um governante absolutista do início da Europa moderna, mas também quando se trata de um conjunto de legisladores, como é o caso das democracias atuais, nas quais as possibilidades de exercício despótico, ainda que em escala menor e mais localizada, aumentam na medida em que os termos da barganha política deixam de ser tão explícitos no regime democrático. Isso acontece porque, por um lado, o número de barganhas 
cresce extraordinariamente, dada a inclusão de parcelas progressivamente maiores da população propiciada pelo sistema democrático, e, por outro, aumenta a ignorância racional dos eleitores, que são apenas afetados indiretamente pelos problemas políticos mais gerais e cujo investimento necessário para eliminar as assimetrias de informação seriam elevados (North, 1990, p. 51).

A questão do abuso de poder por parte dos legisladores não é uma questão fácil e North não pretende dar uma resposta definitiva. Contudo, North mostra seu ceticismo quanto à possibilidade de a simples definição da forma constitucional limitar de modo definitivo as possibilidades de exercício arbitrário do poder. Para isso se fundamenta em Riker (1976), que questiona a tese de que o federalismo, a separação entre os poderes e a democracia sejam causas, no sentido de condições necessárias e suficientes, para regimes políticos de liberdade pessoal. Riker (1976, p. 14) cita uma série de contra-exemplos, tanto de países que preenchiam essas condições e não garantiam essas liberdades, como de países que não preenchiam as duas primeiras condições e apresentavam um grau significativo de liberdades pessoais, o que levou Riker (1976) a concluir que apenas a democracia é uma condição necessária, mas ainda assim não uma condição suficiente, das liberdades políticas, sustentando então a tese de que a liberdade (e, portanto, a limitação do poder arbitrário) pode exigir uma "opinião pública" favorável às liberdades pessoais (Riker, 1976, p. 13). ${ }^{2}$

Embora North não dê uma resposta final à questão, sugerindo que tanto os valores que compõem uma dada cultura quanto instituições políticas formais são importantes para um melhor desempenho do sistema econômico (North, 1990, p. 60 ), impossível não notar a que ponto chega a necessidade de North de investigar as dimensões políticas do Estado, dado o seu papel não apenas de garantir, mas principalmente de definir os direitos de propriedade.

\section{CONCLUSÃO: NORMAS, CONVENÇÕES E A AÇÃO INSTITUCIONAL DO ESTADO}

A análise de North acerca da ação institucional do Estado, embora francamente insatisfatória quanto aos determinantes da atuação institucional do Estado na economia, isto é, na definição e garantia dos direitos de propriedade, possui o mérito de colocar em destaque o papel que o Estado possui nessa tarefa. Ainda que seu modelo neoclássico do Estado padeça de dois graves problemas, a saber, o fato de não incorporar a questão ideológica dos governantes, por um lado, e, por outro, a caracterização do próprio governante como sendo absolutamente autônomo em relação às classes que compõem a sociedade, o que pode ser adequado para o es-

\footnotetext{
${ }^{2} \mathrm{Na}$ seqüência do debate, Vincent Ostrom criticou os critérios utilizados por Riker para definir países como federativos, com independência de poderes e democráticos, além de destacar o papel que as teorias acerca das formas constitucionais possuem na formação da própria opinião pública (Ostrom, 1976).
} 
tudo dos estados absolutistas da Europa no início da era moderna, mas é claramente impróprio para a compreensão das democracias modernas, esse modelo é importante na medida em que aponta para o papel do Estado na definição dos fundamentos institucionais do sistema econômico moderno.

Dessa forma, não considera North o Estado apenas como elemento de proteção dos direitos de propriedade. Como foi visto, o Estado também atribui direitos de propriedade. De uma forma geral, pode-se afirmar que o Estado tem a possibilidade de definir direitos de propriedade sempre que há conflitos quanto à caracterização desses direitos. A idéia de que o Estado deve atuar apenas garantindo os direitos de propriedade parte da hipótese de que os direitos de propriedade podem ser perfeitamente identificados, depois de atribuídos por normas e convenções sociais. De acordo com North, na sociedade moderna isso freqüentemente não é verdadeiro. O Estado possui, muitas vezes, um papel ativo na definição dos direitos de propriedade, definindo que direitos determinados agentes possuem, ao mesmo tempo em que garante esses direitos.

Não se trata de reduzir a importância do mercado e da sociedade, que por meio de convenções e outros mecanismos informais busca criar pequenos grupos e com isso estimular o cumprimento dos contratos e a conseqüente garantia dos direitos de propriedade, como tão bem mostra Posner (2000). ${ }^{3}$ Trata-se, isso sim, de reconhecer que, em determinadas circunstâncias em que a possibilidade de conflito é mais significativa, esses mecanismos sociais de estímulo ao respeito aos contratos e aos direitos de propriedade se mostram freqüentemente insuficientes.

O modelo de análise de North das inter-relações entre o político e o econômico, apresentado em North (1990), representa, por outro lado, um avanço significativo em relação ao modelo neoclássico do Estado (North, 1981), na medida em que não se trata mais de um governante que se contrapõe à sociedade, mas de um conjunto de legisladores que negociam entre si e com os grupos que representam. A idéia aqui é a de agentes (legisladores e grupos de interesse) que negociam entre si buscando uma solução cooperativa, mas onde os legisladores possuem seus próprios interesses e visão de mundo e onde a barganha não é tão "eficiente" como nos modelos neoclássicos de mercado. Embora não seja ainda uma determinação clara e inequívoca da relação entre a esfera política e a esfera econômica, possui a inegável virtude de estabelecer um rumo para pesquisas que reconheçam a importância da interação entre essas duas esferas.

\footnotetext{
${ }^{3}$ A respeito do esforço permanente para reproduzir os vínculos sociais de pequenos grupos no mercado, observa Posner (2000): "Business deals are everywhere forged in bars, restaurants, and private clubs. Business is almost always conducted in a highly social manner. First, participants talk about sports; then, about their families; and only then, perhaps when the dinner or golf game is almost over, do they shake hands on the deal" (Posner, 2000, p. 151).
} 


\section{REFERÊNCIAS BIBLIOGRÁFICAS}

NORTH, Douglass C. (1989). "Institutions and economic growth: a historical introduction.” World Development, v. 17, n 9: 1319-1332, September.

NORTH, Douglass C. (1990). Institutions, Institutional Change and Economic Performance. Cambridge: Cambridge University Press.

NORTH, Douglass C. (1981). Structure and Change in Economic History. New York: W. W. Norton $\&$ Co.

NORTH, Douglass C. (1984). "Transaction costs, institutions and economic history”. Journal of Institutional and Theoretical Economics, v. 140: 7-17. [Reimpresso em FURUBOTN, Eirik G.; RICHTER, Rudolf (Ed.). The new institutional economics: a collection of articles from the Journal of Institutional and Theoretical Economics. College Station, Texas: A \& M University Press, 1991].

NORTH, Douglass C. (1992). Transaction Costs, Institutions, and Economic Performance. San Francisco: ICS Press.

NORTH, Douglass C. (1999). Understanding the Process of Economic Change. London: Institute of Economic Affairs.

NORTH, Douglass C., THOMAS, Robert Paul (1973). The Rise of the Western World: a new economic history. Cambridge: Cambridge University Press.

OSTROM, Vincent. (1976). "Response to William Riker's comments”. Public Choice, v. 27: 16-19.

POSNER, Eric A. (2000). Law and Social Norms. Cambridge, Mass.: Harvard University Press.

RIKER, William H. (1976). “Comments on Vicent Ostrom’s paper”. Public Choice, v. 27: 13-15. 